\title{
Silencing of CD44 Expression in Prostate Cancer by Hypermethylation of the CD44 Promoter Region
}

\author{
Nicole S. Verkaik, Gert J. van Steenbrugge, Wytske M. van Weerden, \\ Marion J. Bussemakers, and Theodorus H. van der Kwast
}

Department of Experimental Urology (NSV, GJvS, WMvW) and Pathology (THvdK), Josephine Nefkens Institute, Erasmus University, Rotterdam, and Department of Urology (MJB), University of Nijmegen, Nijmegen, The Netherlands

\begin{abstract}
SUMMARY: Loss of the CD44 transmembrane glycoprotein in primary prostate cancer has been shown to be associated with unfavorable clinical behavior. Moreover, the majority of prostate cancer metastases lack expression of this molecule. The mechanism of CD44 silencing in prostate cancer was investigated using both patient material and in vivo-propagated human prostate cancer xenografts. In 9 of 11 lymph node metastases of prostate cancer, we demonstrated by methylation-sensitive restriction enzyme digestion that the promoter region of the CD44 gene is methylated, indicating that this represents a major mechanism of CD44 silencing. Similarly, in 6 out of 12 in vivo-growing human prostate carcinoma xenograft models, hypermethylation of the $C D 44$ gene was found. The extent of $\mathrm{CpG}$ island methylation was investigated by nucleotide sequencing after bisulphite modification of the CD44 promoter region. In the xenografts displaying hypermethylation, the examined $14 \mathrm{CpG}$ sites in the CD44 transcription regulatory domain, including a Sp1 binding site, were consistently methylated. This correlated with reduced CD44 expression or lack of CD44 expression at mRNA and protein levels. In the xenografts lacking hypermethylation of the CD44 gene, high levels of CD44 mRNA and protein were expressed in some models, whereas in others CD44 mRNA expression was only detectable by RT-PCR and the CD44 protein could hardly be detected or was not detected at all. The results indicate that, in most prostate cancers, loss of CD44 expression is associated with extensive hypermethylation of the CpG island of the CD44 promoter region, but other, posttranscriptional mechanisms may also lead to CD44 loss. (Lab Invest 2000, 80:1291-1298).
\end{abstract}

$P$ rostate cancer is the second leading cause of death among males in the United States, Western Europe, and Australia (Parker et al, 1997). In the last decade, as the incidence of prostate cancer has increased with the aging of the western male population, so has its detection improved with the introduction of prostate-specific antigen serum testing and a growing awareness of the disease (Bangma et al, 1995). Concern has been raised about the potential risk of overtreatment of early-detected prostate cancers (De Koning and Schröder 1998; Zappa et al, 1998). Insight into the nature of a tumor (ie, whether it is aggressive or nonaggressive) at diagnosis could help to determine the most appropriate therapy. For that reason, a considerable effort is directed at the search for markers predicting aggressiveness or metastatic potential of prostate cancer.

CD44 is a receptor for hyaluronate, plays a role in cell-cell and cell-matrix interactions, and has been implicated in tumor growth and migration (Aruffo et al,

Received April 19, 2000.

This work was supported by Biomed II Markers of Prostate Cancer, grant 95/C/35109, of the Europe Against Cancer Program of the European Community.

Address reprint requests to: Prof. Dr. Th. H. van der Kwast, Department of Pathology, Josephine Nefkens Institute, Erasmus University, Postbox 1738, 3000 DR Rotterdam, The Netherlands. Fax: 3110 4089487; E-mail: vanderkwast@path.fgg.eur.nl
1990; Naor et al, 1997; Sherman et al, 1994). The CD44 gene consists of 20 exons, of which at least 10 are alternatively spliced (Tölg et al, 1993). Upregulation and down-regulation of both the standard CD44 protein, which includes no alternative exons, and variant proteins, have been correlated with the metastatic behavior of various human cancers (Ponta et al, 1994; Sy et al, 1997). Recently, some studies demonstrated that loss of CD44 was associated with increased grade and pathological stage of prostate cancer. In addition to these conventional parameters, loss of CD44 proved to predict tumor recurrence and biochemical progression (De Marzo et al, 1998; Kallakury et al, 1996; Noordzij et al, 1997). Therefore, knowledge of the mechanisms responsible for transcriptional down-regulation of the CD44 gene could be helpful for the design of specific tools for identifying prostate cancers with aggressive potential.

CpG island methylation in the regulatory sequence of a gene is known to be a nonmutational mechanism that can cause transcriptional suppression. This is accomplished through the formation of repressor complexes, including methyl-CpG-binding proteins (MeCPs) and histone deacetylases, leading to an inactive chromatin structure (Kass et al, 1997; Nan et al, 1998; Razin, 1998). When, as a consequence of DNA methylation, tumor suppressor genes or growthinhibiting genes are down-regulated, cancer progression can be promoted (Bird, 1996; Zingg and Jones, 
1997). Also for prostate cancer, CpG methylation has been described to be a mechanism that inactivates several genes (Jarrard et al, 1996; Schulz, 1998), including the E-cadherin (Graff et al, 1995) and GSTP1 genes (Lee et al, 1997). These observations were the motivation for a previous study that was to investigate whether and to what extent methylation of the CD44 promoter was correlated with loss or decrease of its expression. We, and others, found that this was true for the examined human prostatic carcinoma cell lines: DU145, LNCaP, PC3, PC-346C, and TSU (Lou et al, 1999; Verkaik et al, 1999). In a recent study, methylation-specific restriction enzyme digestion followed by PCR analysis was used to detect the presence of methylated CD44 DNA in 31 of 40 primary prostate cancers and in 3 of 4 distant metastases. These data support hypermethylation of the CD44 gene as an important mechanism of CD44 silencing in clinical prostate cancer (Lou et al, 1999). Here, we demonstrate hypermethylation of the promoter region of the CD44 gene in the majority of lymph node metastases using methylation-sensitive restriction enzyme analysis. Further analysis, using bisulphite genomic sequencing, of methylation patterns in CD44-positive and -negative human prostate cancer xenografts demonstrated that, in most cases, loss of CD44 mRNA and protein expression was associated with severe methylation of the investigated $\mathrm{CpG}$ sites of the CD44 promoter CpG island.

\section{Results}

\section{Methylation Status of CD44 Gene Promoter Region in Benign Prostatic Tissue and Prostate Cancer Lymph Node Metastases}

Clinical studies show that prostatic epithelial cells of benign prostatic hyperplasia (BPH) tissue, representative for the normal prostate, are positive for CD44 protein expression, whereas about $80 \%$ of the lymph node metastases investigated have complete loss of CD44 protein expression (Noordzij et al, 1997, 1999). Methylation-sensitive restriction enzyme analysis was performed on three BPH samples and 11 lymph node metastases. Methylation of the $\mathrm{CpG}$ in the Cfol recognition site within the CD44 promoter would prevent digestion of the 531-bp EcoRV-BamHI CD44 promoter fragment into a 365 and 166-bp band (Fig. 1A). Genomic DNA was digested with an excess of $\mathrm{Cfol}$ to ensure complete digestion. Furthermore, genomic

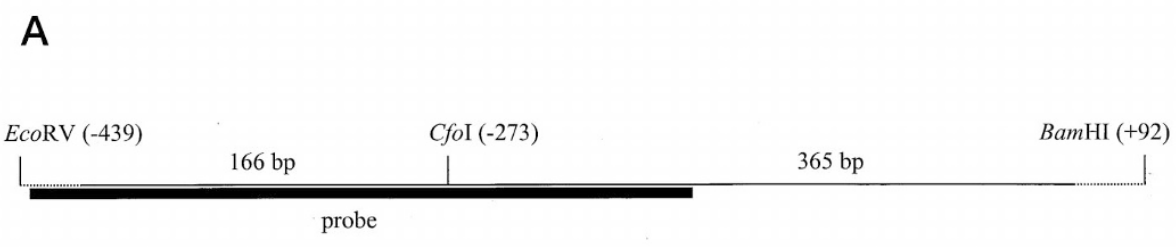

B
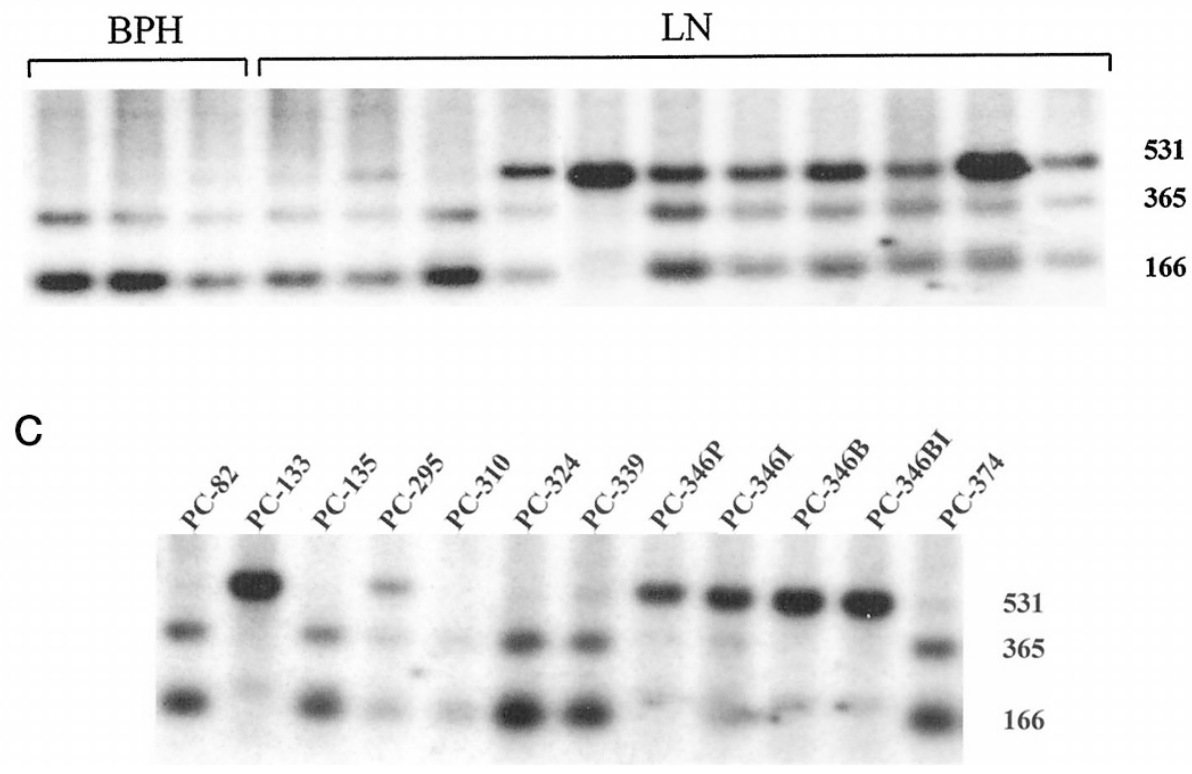

Figure 1.

Methylation-sensitive restriction enzyme analysis of clinical prostate cancer samples and xenograft models. A, Restriction map of the CD44 $5^{\prime}$ CpG island. The bold line represents the 202-bp probe used for Southern blot hybridization. The 531-bp EcoRV/BamHI fragment contains one Cfol restriction site, resulting in a 166-bp and a 365-bp fragment if the internal $\mathrm{CpG}$ of $\mathrm{Cfol}$ is unmethylated. Restriction fragments were hybridized with a 202-bp CD44 promoter probe. B, Southern blot analysis of clinical benign prostatic hyperplasia (BPH) samples and prostate cancer lymph node (LN) metastases. C, Southern blot analysis of the human prostate cancer xenograft models. 
DNA of the prostatic cancer cell line TSU was added as an additional sample in each experiment. The CD44 promoter in TSU is known to be completely unmethylated (Verkaik et al, 1999) and therefore served as a control on the efficiency of the digestion reaction. None of the BPH, but 9 of 11 lymph node metastases, showed the 531-bp fragment in addition to the 365and 166-bp fragments (Fig. 1B). This indicates that the BPH samples are unmethylated, whereas in 9 of 11 lymph node metastases of the prostate, part of the tissue has a methylated CD44 promoter. The observed number of lymph node metastases with a methylated CD44 promoter (9/11) corresponds well with the $80 \%$ of CD44 immuno-negative lymph node metastases found previously by Noordzij et al (1999).

\section{Methylation of the CD44 Promoter and Correlation with CD44 mRNA and Protein Expression in Human Prostate Cancer Xenografts}

To investigate the relation between CD44 expression (mRNA and protein) and the extent of methylation in the CD44 promoter region and in an in vivo system, we analyzed a panel of in vivo human prostatic carcinoma xenografts (Table 1). Immunostaining of the different xenografts with a humanspecific monoclonal antibody showed a homogeneous and strong membranous expression in the PC-82 (Fig. 2A) and PC-374 models, a homogenous and moderate expression in PC-135 and PC-310, and a loss of expression in the PC-133, PC-295, PC-339, PC-346P, PC-346I, PC-346B, and PC346BI models (Fig. 2B). Immunostaining of different mouse passages, varying from 1 to 40 , showed that CD44 protein expression in the xenograft models remained stable over time (data not shown).

Using reverse transcriptase-polymerase chain reaction (RT-PCR), xenografts PC-82, PC-135, PC295, PC-310, PC-324, PC-339, and PC-374 displayed both CD44 seconds (250 bp fragment) and CD44 variant mRNA (650 bp) (Fig. 3). PC-346B and $\mathrm{PC}-346 \mathrm{Bl}$ showed reduced expression of the stan- dard CD44 mRNA transcript. Finally, PC-133, PC346P, and PC-346I were completely negative. Specificity of the products was checked by hybridization of the RT-PCR products with a radioactively labeled internal oligonucleotide. Omission of reverse transcriptase to the reaction gave a negative result. To get more insight into the level of CD44 mRNA expression, a Northern blot analysis was performed as well. On a Northern blot, PC-82 and PC-374 were clearly positive for CD44 mRNA (data not shown), confirming the strong CD44 expression in these xenografts, as was also found with the immunohistochemical staining. All other xenografts showed no signal, meaning that they are either CD44-negative or that the expression is too low to be detected by Northern blot analysis.

The methylation status of the CD44 promoter region in the xenografts was analyzed by means of methylation-sensitive restriction enzyme analysis (Fig. 1C). No evidence for methylation of the CD44 promoter region was found in PC-82, PC-135, PC310, and PC-374 (expressing both CD44 mRNA and protein) because the 531-bp fragment of the EcoRVBamHI fragment was completely digested into the 365-bp and 166-bp fragments by Cfol. PC-324 and PC-339 were not methylated at the investigated $\mathrm{CpG}$ site. These xenografts were CD44 mRNApositive in the RT-PCR assay but negative on the Northern blot and in the immunohistochemical staining. PC-295 was also only positive in the RTPCR assay, but it proved to be heterogeneous with respect to the methylation status of the CD44 promoter region. Finally, the PC-346 panel and PC-133, which had a low or absent CD44 mRNA expression, were completely methylated at the Cfol site. Although all four PC-346 xenograft models derived from the same primary tumor, a weak CD44 mRNA signal was present in PC-346B and PC-346BI. This could originate from a small population of CD44positive cells within the xenografts because the original primary prostate tumor exhibited a hetero-

Table 1. Main Characteristics and Results of CD44 Expression and CD44 Methylation Pattern of the Human Prostatic Xenograft Models

\begin{tabular}{clccccc}
\hline Tumor model & Origin & $\begin{array}{c}\text { Androgen } \\
\text { sensitivity }\end{array}$ & $\begin{array}{c}\text { Methylation } \\
\text { status }\end{array}$ & $\begin{array}{c}\text { CD44 mRNA } \\
\text { RT-PCR }\end{array}$ & $\begin{array}{c}\text { CD44 mRNA } \\
\text { Northern blot }\end{array}$ & $\begin{array}{c}\text { CD44 } \\
\text { protein }\end{array}$ \\
\hline PC-82 & RP & yes & - & + & + & + \\
PC-133 & bone & no & + & - & - & - \\
PC-135 & LN & no & - & + & - & + \\
PC-295 & LN & yes & $+/$ & + & - & - \\
PC-310 & RP & yes & - & + & - & + \\
PC-324 & TUR-P & no & - & + & - & - \\
PC-339 & TUR-P & no & - & + & - & - \\
PC-346P & TUR-P & yes & + & - & - & - \\
PC-346I & & no & + & - & - & - \\
PC-346B & & yes & + & $+/-$ & - & - \\
PC-346BI & & no & + & $+/-$ & - & - \\
PC-374 & skin & no & - & + & + & ++ \\
\hline
\end{tabular}

RP, radical prostatectomy; LN, Iymph node; TUR-P, trans-urethral resection of the prostate. 


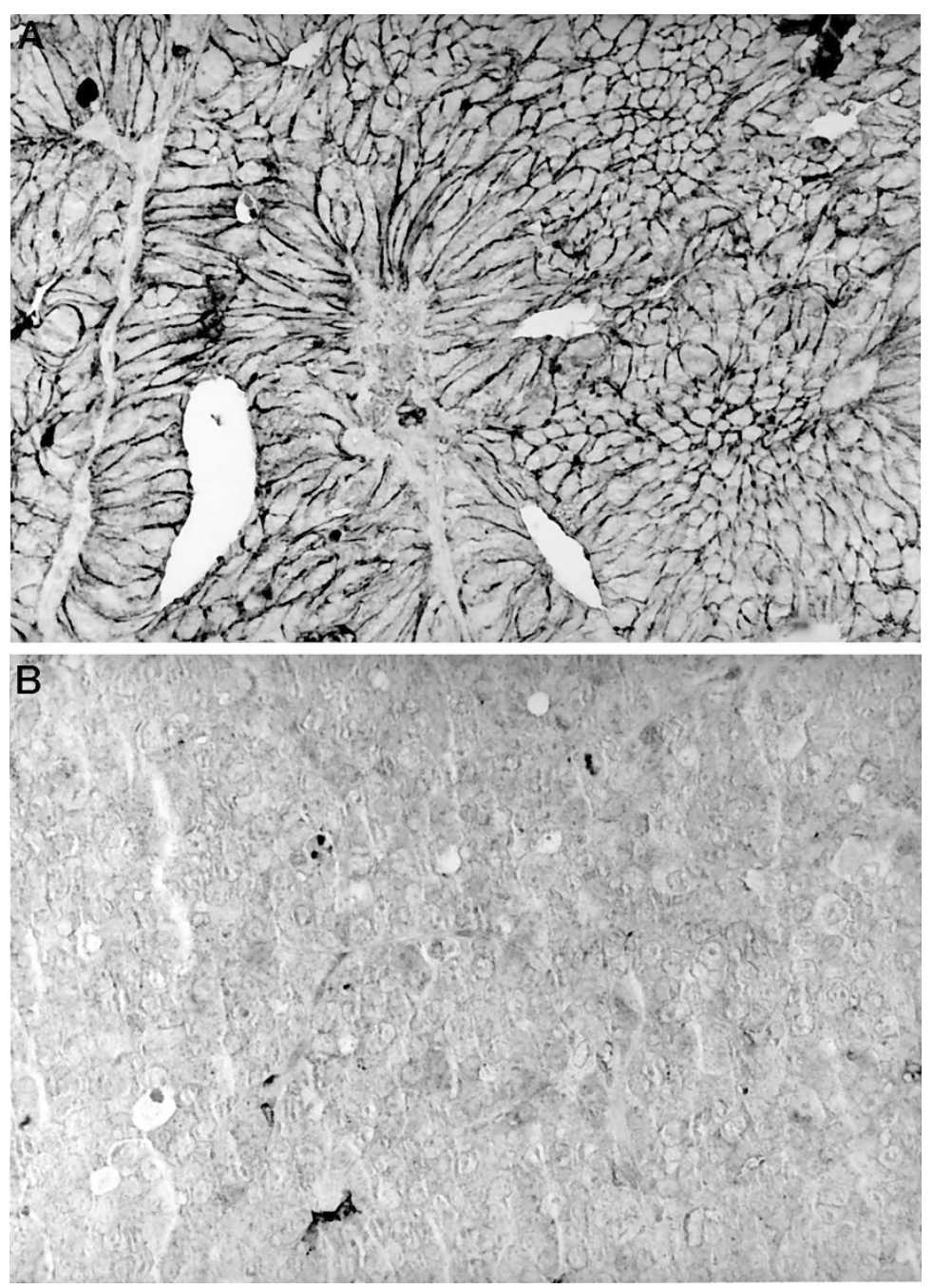

Figure 2.

CD44 protein expression in human prostatic carcinoma xenograft models. Slides were stained with an antibody recognising both the standard protein and all splice variants. A, PC-82 xenograft model, with strong membrane staining. B, PC-346P xenograft model, lacking CD44 expression. $(\times 400)$

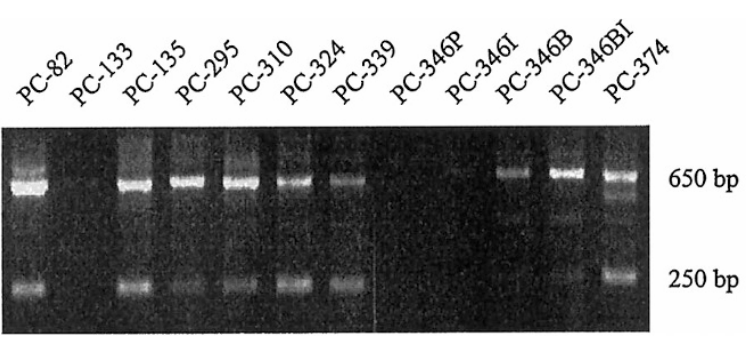

Figure 3.

CD44 mRNA expression in human prostatic carcinoma xenograft models. RT-PCR products were visualized by ethidium bromide staining. The smallest 250-bp band represents standard CD44 mRNA. All other bands are CD44 splice variants.

geneous CD44 protein expression pattern. Table 1 summarizes the results of restriction enzyme digestion with methylation-sensitive Cfol, RT-PCR, and Northern blot analysis for CD44 mRNA expression and immunohistochemistry for CD44 protein expression on the examined 12 xenograft models. In conclusion, at least 9 of 12 xenograft models have a methylation pattern consistent with a role of methylation in CD44 silencing.

\section{Sequencing of Bisulphite Modified Genomic CD44 DNA Derived from Prostate Cancer Xenograft Models}

Because methylation-sensitive restriction enzyme analysis only gives limited information about the methylation status, we analyzed a group of five xenograft models in more detail using bisulphite genomic sequencing with a region of $14 \mathrm{CpGs}$ within the CD44 promoter $\mathrm{CpG}$ island, including the central $\mathrm{CpG}$ of a Sp1 site. For each xenograft, eight independent clones were sequenced. Sequencing results of all these clones are shown in Figure 4. PC-82 and PC135, both CD44 mRNA- and protein-positive, showed an absence of methylation throughout the CpG island, except for the most upstream CpG. PC-324, positive for CD44 mRNA but negative for CD44 protein expression, was unmethylated in the CD44 promoter region. In contrast, the CD44 mRNA- and protein-negative PC-346P and PC-346B display heavily methylated 


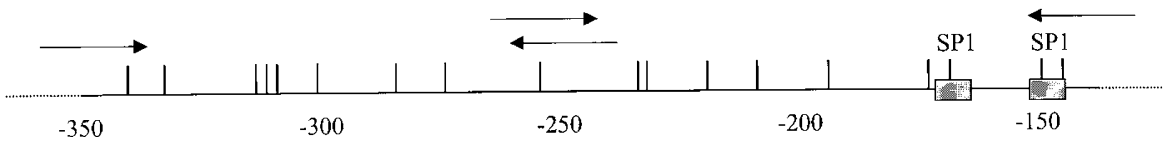

\begin{tabular}{|c|c|c|c|c|c|c|c|c|}
\hline PC-346P & 0 & $\infty$ & $\bullet$ & - & $\infty$ & - & 0 & - \\
\hline $\mathrm{PC}-346 \mathrm{~B}$ & 0 & $\infty$ & 0 & - & $\infty$ & - & - & \\
\hline PC-82 & 0 & 0000 & 0 & 0 & $\infty$ & 0 & 0 & 0 \\
\hline PC-135 & 0 & 0000 & 0 & 0 & $\infty$ & 0 & 0 & 0 \\
\hline PC-324 & 0 & 0000 & $\odot$ & 0 & $\infty$ & 0 & 0 & 0 \\
\hline
\end{tabular}

\section{Figure 4.}

Bisulphite genomic sequencing of the $C D 44$ promoter $\mathrm{CpG}$ island of a panel of human prostatic xenograft models. The upper part shows the position of each individual $\mathrm{CpG}$ in the $C D 44$ promoter region (indicated as a vertical bar). The arrows indicate the position of the nested primer sets used. The circles in the lower part represent the methylation status of each individual $\mathrm{CpG}$, which is the sequencing result of 8 different clones: an open circle is completely unmethylated; an open circle with a black centre is predominantly unmethylated; a grey circle is equally unmethylated and methylated; a black circle with a white centre is predominantly methylated; and a black circle is completely methylated.

$\mathrm{CpG}$ islands, including the $\mathrm{CpG}$ of the $\mathrm{Sp} 1$ site. Although the methylation pattern of the $\mathrm{CpG}$ island within a xenograft varied to some extent, the CpG of the Cfol restriction site used for the methylationsensitive restriction enzyme analysis always proved to be methylated in a CD44-negative xenograft. This would suggest that the methylation status of this site is highly representative of the methylation status of the xenograft analyzed.

\section{Discussion}

Several mechanisms may account for loss of suppressor gene function, including allelic loss combined with mutation, homozygous deletions, hypermethylation of $\mathrm{CpG}$ islands in the promoter region, abnormal splicing, and down-regulation by growth factor or cytokinemediated activation of cell membrane receptors. Previous in vitro experiments showed that loss of CD44 expression in human prostatic carcinoma cell lines was correlated with methylation of the CD44 promoter region. In fact, direct involvement of hypermethylation in CD44 suppression was supported by the observation that the demethylating agent 5-azacytidine could induce CD44 expression in the otherwise CD44negative PC346C prostate cancer line (Verkaik et al, 1999). In the current study, we present evidence that not only in vitro, but also in vivo, promoter methylation is one of the mechanisms by which CD44 mRNA expression is down-regulated in human prostate cancer.

We confirmed the importance of methylation as a suppressive mechanism for CD44 in vivo (Lou et al, 1999) by our results obtained with the clinical tumor samples. None of the BPH samples, which are representative for the normal prostate, were methylated, whereas 9 of 11 lymph node metastases showed methylation of the $\mathrm{CD} 44$ promoter $\mathrm{CpG}$ island. In addition to the 531-bp fragment in the methylationsensitive restriction enzyme analysis, which represents methylation of the CD44 promoter DNA, most of the lymph node metastases show the 365- and 166-bp fragments as well. The bisulphite sequencing result (Fig. 4) shows that the methylation status of the Cfol restriction site (CpG at position -273) is representative of the overall methylation status of a sample. Therefore, we think it is not likely that the presence of the Cfol digested fragments in the lymph node metastasis samples are the result of methylation pattern differences within the sample. However, contamination of all samples with (CD44-positive) lymphocytes must be considered very likely, because we did not perform microdissection for isolation of genomic DNA. Although there is a clear correlation between reduced expression of CD44 or lack of CD44 expression and methylation of the CD44 promoter, it remains to be determined whether CD44-negative prostate cancers caused by methylation of the CD44 promoter region behave differently from CD44-negative tumors that do not show this methylation.

In addition, the availability of twelve human prostate cancer xenografts (Van Steenbrugge et al, 1994; Van Weerden et al, 1996) gave us the opportunity to perform a detailed analysis of CD44 mRNA expression, CD44 protein expression, and the extent of promoter methylation in an in vivo system. This panel of 12 xenograft models has been well characterized and consists of both androgen-dependent and androgen-independent tumor models with varying degrees of differentiation representing the most common types of prostatic adenocarcinomas (Van Steenbrugge et al, 1994; Van Weerden et al, 1996). Slides of all xenograft models were immunohistochemically stained for CD44 protein (standard and all splice variants). No correlation was found between CD44 expression and androgen dependence or expression of prostate-specific markers, such as the androgen receptor and prostate-specific antigen (Van Steenbrugge et al, 1994). Based on methylation-sensitive restriction enzyme analysis, CD44 mRNA, and CD44 protein expression, prostate cancer xenografts with and without a methylated $\mathrm{CpG}$ island in the promoter region of the $C D 44$ gene could be distinguished. Five 
xenograft models, with low to undetectable CD44 mRNA and no CD44 protein expression, showed complete methylation of the CpG island. In addition, four xenograft models with weak to strong CD44 mRNA expression and detectable protein level had an unmethylated $C D 44$ promoter region. So 9 of 12 xenograft models have a methylation pattern that is consistent with a role for methylation in CD44 silencing. However, the three remaining xenograft models were partially or completely unmethylated, and no protein expression could be detected. In these cases, CD44 mRNA expression was only detectable by the more sensitive RT-PCR analysis. It cannot be excluded that, in these xenografts, CD44 is expressed below our detection level. Unfortunately, at the moment no data are known about the loss of heterozygosity of the CD44 gene in any of the previously examined prostatic cancer cell lines (Verkaik et al, 1999) or in the human prostatic xenograft models studied in this paper.

Detailed analysis of the methylation of CpG islands by bisulphite genomic sequencing revealed that, in both PC-346P and PC-346B, the CD44 promoter region was heavily methylated throughout the $\mathrm{CpG}$ island, including the Sp1 site, whereas PC-82, PC135, and PC-324 were almost completely unmethylated at their CpGs. Strikingly, methylation of some CpG sites, most notably the most upstream CpG site, could be detected in these xenograft models. This observation suggests that care must be taken when choosing a restriction enzyme for detection of methylated CD44 promoter region by methylation-sensitive restriction enzyme digestion, followed by PCR analysis (Lou et al, 1999). The Cfol site seems to be a very informative one, because its internal $\mathrm{CpG}$ is always methylated in CD44-negative samples.

Suppression of transcription by methylation is the result of chromatin structure changes mediated by the transcriptional repression complex containing MeCPs and deacetylases (Razin, 1998). Bisulphite genomic sequencing of two CD44-negative xenografts (PC$346 \mathrm{P}$ and $\mathrm{PC}-346 \mathrm{~B})$ showed severe methylation throughout the CD44 promoter $\mathrm{CpG}$ island. The investigated region contains $14 \mathrm{CpGs}$, one of which is located in a Sp1 binding site. The central CpG of this Sp1 site is completely methylated as well, whereas the Sp1 in the CD44-positive xenografts are completely unmethylated. It has been described that the Sp1 transcription factor can bind DNA and activates transcription even when the binding site is methylated (Holler et al, 1988). So it does not seem likely that CD44 is repressed by direct inhibition of Sp1 transcription factor binding to the methylated Sp1 site. However, Kudo (1998) showed that, for the human leukosialin gene (CD43), MeCP2 represses Sp1activated transcription. Instead of a direct effect, it is likely that CD44 expression is suppressed by the indirect effect of the chromatin structure changes mediated by binding of MeCPs close to the Sp1.

In conclusion, this study demonstrates that methylation of the promoter region of the CD44 gene represents a major mechanism of silencing CD44 expres- sion in prostate cancer metastases and is correlated with reduced or loss of CD44 expression. However, it cannot be excluded that other factors may also result into loss of CD44 expression. Both the in vitro human prostate cancer cell lines and the in vivo xenograft models may represent useful models for designing tools to detect methylation of the CD44 gene in clinical samples and for studying the involvement of methylating enzymes in prostate cancer.

\section{Materials and Methods}

\section{Tumor Models and Clinical Tissue Samples}

A panel of 12 in vivo xenograft models (listed in Table 1) and 14 freshly frozen tissue samples were used for studying the relationship between CD44 expression and methylation of the CD44 promoter region. The main characteristics of the xenografts, propagated by subcutaneous inoculation, have been described previously (Noordzij et al, 1996; Van Steenbrugge et al, 1994; Van Weerden et al, 1996). All tissues were derived from xenografts grown in male mice with androgen substitutes by means of a Silastic testosterone implant. PC-346P and PC-346B originated from the same primary prostate tumor, but two separate transurethrally resected prostate chips were used for implantation into nude mice. The original primary prostate tumor exhibited a heterogeneous CD44 protein expression pattern. PC-346I is an androgen independent subline of the PC-346P xenograft model, as is $\mathrm{PC}-346 \mathrm{BI}$ of the PC-346B model. Frozen prostatic tissue from three prostatectomy specimens, lacking tumor but containing both stromal and glandular cells (ie, benign hyperplasia), and frozen tissue samples of 11 lymph node metastases were retrieved from the Rotterdam and Nijmegen prostate tissue bank. The lymph node metastases were selected for their high content $(>90 \%)$ of tumor tissue.

\section{Reverse Transcriptase-Polymerase Chain Reaction and Northern Blot Analysis}

RNA isolation from xenograft material and RT-PCR analysis was performed as described (Verkaik et al, 1999). To avoid amplification of mouse RNA of the xenograft samples, a human-specific primer pair was used in the PCR reaction: the sense primer CD44-5S (exon 5): 5' ACAGCACAGACAGAATCCCTG 3' and the intron-spanning antisense primer CD44-17AS (exon 17/19): 5' TCTTCTGCCCACACCTTCTCC 3'. These primers amplify both CD44 standard cDNA and all possible splice variants.

For Northern hybridization, total RNA (20 $\mu \mathrm{g})$ was electrophoresed on a $1 \%$ agarose formaldehyde gel and transferred to Hybond $\mathrm{N}+$. RNA was fixed to the membrane by UV-cross-linking. The blot was hybridized overnight at $60^{\circ} \mathrm{C}$ with a $250-\mathrm{bp} \alpha^{32} \mathrm{P}-\mathrm{dATP}$ labeled CD44 standard cDNA probe (RT-PCR product obtained with the CD44-5S and CD44-17AS primers) in a hybridization mix containing $0.5 \mathrm{M}$ $\mathrm{Na}_{2} \mathrm{HPO}_{4} \cdot 2 \mathrm{H}_{2} \mathrm{O}$ (pH 7.2), $7 \%$ SDS, $1 \% \mathrm{BSA}$ and $1 \mathrm{~mm}$ EDTA. The filter was washed with $1 \times$ SSC/0.1\% SDS 
Table 2. Primers Used for Bisulphite Genomic Sequencing ${ }^{a}$

\begin{tabular}{|c|c|c|c|}
\hline Primer set & Orientation & Sequence $5^{\prime} \rightarrow 3^{\prime}$ & Genomic position \\
\hline 1 & sense & ITTGTTTTAGTYGGATTIAG & -417 \\
\hline 1 & antisense & ĀTCGAAAAACCTAAAATA-ATC & -215 \\
\hline $1^{*}$ & sense & $\overline{\text { GGTGIAAGGTTTTAYGGTTYG }}$ & -354 \\
\hline $1^{*}$ & antisense & AАТАС̄СТATACCTCСААACC & -239 \\
\hline 2 & sense & 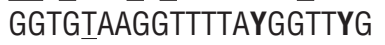 & -354 \\
\hline 2 & antisense & AATAĀCGAACCGAACCTAAC & +50 \\
\hline $2^{*}$ & sense & AGTGGGGTTYGGAGGTATAG & -263 \\
\hline $2^{*}$ & antisense & AACAACCCTCCCRAACRAAC & -133 \\
\hline
\end{tabular}

${ }^{*}$ Nested primer pair $Y=C$ or $T ; R=G$ or $A$.

${ }^{a}$ Sequence differences between modified and unmodified DNA are underlined. Differences between methylated/modified and unmethylated/modified are in boldface.

and $0.3 \times \mathrm{SSC} / 0.1 \% \mathrm{SDS}$ at $60^{\circ} \mathrm{C}$ and exposed to $X$-ray film (Fuji Photo Film, Düsseldorf, Germany).

\section{Restriction Enzyme Digestion and Southern Blot Analysis}

Genomic DNA of xenografts or clinical samples was digested first with EcoRV and BamHI as described (Verkaik et al, 1999), followed by a digestion with an excess of the methylation-sensitive restriction enzyme Cfol (recognition sequence GCGC). The 531-bp EcoRV/BamHI fragment contains one Cfol restriction site, resulting in a 166-bp and a 365-bp fragment if the internal $\mathrm{CpG}$ of $\mathrm{Cfol}$ is unmethylated (Fig. 1A). Subsequent agarose gel electrophoreses and Southern blot hybridization with a CD44 promoter fragment was performed as described (Verkaik et al, 1999) .

\section{Immunohistochemistry}

Formalin-fixed and paraffin-embedded slides of the xenograft models were stained with a monoclonal antibody recognizing both the standard form and all possible splice variants of CD44 as described (Verkaik et al, 1999). Immunohistochemistry was performed on the same tumor tissue specimens as were used for DNA and RNA isolations.

\section{Bisulphite Modification of Genomic DNA PRIVATE}

Genomic DNA was isolated from xenograft tissue (Sambrook et al, 1989) and predigested with EcoRI. DNA $(1 \mu \mathrm{g})$ in a total volume of $50 \mu \mathrm{l}$ was denaturated by adding $\mathrm{NaOH}$ to a final concentration of $0.3 \mathrm{M}$ and incubating for 15 minutes at $37^{\circ} \mathrm{C}$. Thirty microliters of $10 \mathrm{~mm}$ hydroquinone (Sigma, St. Louis, Missouri) and $520 \mu \mathrm{l}$ of $4 \mathrm{M}$ sodium bisulphite (Sigma) at pH 5.0, both freshly prepared, were added and samples were incubated overnight at $55^{\circ} \mathrm{C}$. Modified DNA was purified using GeneClean according to the manufacturer (Bio 101, La Jolla, California) and eluated in $50 \mu \mathrm{l}$ of water. Modification was completed by $\mathrm{NaOH}$ treatment (final concentration, $0.3 \mathrm{M}$ ) for 15 minutes. at $37^{\circ} \mathrm{C}$. The solution was neutralized by addition of $\mathrm{NH}_{4} \mathrm{OAc}, \mathrm{pH} 7$, to $3 \mathrm{M}$ and the DNA was ethanol precipitated, dried, resuspended in water, and stored at $-20^{\circ} \mathrm{C}$.

\section{Genomic Sequencing}

Bisulphite-modified DNA (100 ng) was amplified in a nested PCR analysis with the human CD44 promoter specific nested primer set 1 or 2 (Table 2). All primers recognised methylated and unmethylated DNA equally well. PCR conditions were as follows: $94^{\circ} \mathrm{C}$ for 5 minutes, followed by 35 cycles of $94^{\circ} \mathrm{C}, 1$ minute; $50^{\circ} \mathrm{C}, 1$ minute; $72^{\circ} \mathrm{C}, 1$ minute for amplification, and a final extension for 10 minutes at $72^{\circ} \mathrm{C}$. The PCR mixture contained one unit SuperTaq DNA polymerase (Sphaero Q, HT Biotechnology, Cambridge, United Kingdom), $1 \times$ buffer (Sphaero Q) with $1.5 \mathrm{~mm}$ $\mathrm{MgCl}_{2}, 100 \mathrm{ng}$ of each primer, and $0.2 \mathrm{~mm}$ dNTPs in a final volume of $50 \mu \mathrm{l}$. To obtain products for sequencing, a second round of PCR was performed using nested primers. PCR was performed as above. Cloning of PCR fragments was performed with the pGEM-T Cloning kit (Promega, Madison, Wisconsin) by a shotgun procedure according to the manufacturer's protocol. Sequence analysis of eight clones per sample was performed by dideoxy-nucleotide chain termination using a T7 sequence kit (Pharmacia, Uppsala, Sweden).

\section{References}

Aruffo A, Stamenkovic I, Melnick M, Underhill CB, and Seed B (1990). CD44 is the principal cell surface receptor for hyaluronate. Cell 61:1303-1313.

Bangma CH, Blijenberg BG, and Schröder FH (1995). Prostate specific antigen: Its clinical use and application in screening for prostate cancer. Scand J Clin Lab Invest Suppl 221:35-44.

Bird AP (1996). The relationship of DNA methylation to cancer. Cancer Surv 28:87-101.

De Koning HJ and Schröder FH (1998). PSA screening for prostate cancer: The current controversy. Ann Oncol 9:12931296.

De Marzo AM, Bradshaw C, Sauvageot J, Epstein Jl, and Miller GJ (1998). CD44 and CD44v6 downregulation in clinical prostatic carcinoma: Relation to Gleason grade and cytoarchitecture. Prostate 34:162-168.

Graff JR, Herman JG, Lapidus RG, Chopra H, Xu R, Jarrard DF, Isaacs WB, Pitha PM, Davidson NE, and Baylin SB (1995). E-cadherin expression is silenced by DNA hypermethylation in human breast and prostate carcinomas. Cancer Res 55:5195-5199. 
Holler M, Westin G, Jiricny J, and Schaffner W (1988). Sp1 transcription factor binds DNA and activates transcription even when the binding site is CpG methylated. Genes Dev 2:1127-1135.

Jarrard DF, Bova GS, and Isaacs WB (1996). DNA methylation, molecular genetic, and linkage studies in prostate cancer. Prostate Suppl 6:36-44.

Kallakury BVS, Yang F, Figge J, Smith KE, Kausik SJ, Tacy NJ, Fisher HAG, Kaufman R, Figge H, and Ross JS (1996). Decreased levels of CD44 protein and mRNA in prostate carcinoma. Cancer 78:1461-1469.

Kass SU, Pruss D, and Wolffe AP (1997). How does DNA methylation repress transcription? Trends Genet 13:444449.

Kudo S (1998). Methyl-CpG-binding protein MeCP2 represses Sp1-activated transcription of the human leukosialin gene when the promoter is methylated. Mol Cell Biol 18: 5492-5499.

Lee WH, Isaacs WB, Bova GS, and Nelson WG (1997). CG island methylation changes near the GSTP1 gene in prostatic carcinoma cells detected using the polymerase chain reaction: A new prostate cancer biomarker. Cancer Epidemiol Biomarkers Prev 6:443-450.

Lou W, Krill D, Dhir R, Becich MJ, Dong JT, Frierson HFJ, Isaacs WB, Isaacs JT, and Gao AC (1999). Methylation of the CD44 metastasis suppressor gene in human prostate cancer. Cancer Res 59:2329-2331.

Nan X, Ng HH, Johnson CA, Laherty CD, Turner BM, Eisenman $\mathrm{RN}$, and Bird A (1998). Transcriptional repression by the methyl-CpG-binding protein MeCP2 involves a histone deacetylase complex. Nature 393:386-389.

Naor D, Sionov RV, and Ish-Shalom D (1997). CD44: Structure, function, and association with the malignant process. Adv Cancer Res 71:241-319.

Noordzij MA, Van Steenbrugge GJ, Schröder FH, and Van Der Kwast TH (1999). Decreased expression of CD44 in metastatic prostate cancer. Int J Cancer 84:478-483.

Noordzij MA, Van Steenbrugge GJ, Verkaik NS, Schröder FH, and Van Der Kwast TH (1997). The prognostic value of CD44 isoforms in prostate cancer patients treated by radical prostatectomy. Clin Cancer Res 3:805-815.

Noordzij MA, Van Weerden WM, De Ridder CM, Van Der Kwast TH, Schröder FH, and Van Steenbrugge GJ (1996). Neuroendocrine differentiation in human prostatic tumor models. Am J Pathol 149:859-871.

Parker SL, Tong T, Bolden S, and Wingo PA (1997). Cancer statistics. CA Cancer J Clin 47:5-27.
Ponta H, Sleeman J, Dall P, Moll J, Sherman L, and Herrlich $P$ (1994). CD44 isoforms in metastatic cancer. Invasion Metastasis 14:82-86.

Razin A (1998). CpG methylation, chromatin structure, and gene silencing: A three-way connection. EMBO J 17:49054908.

Sambrook J, Fritsch EF, and Maniatis T (1989). Isolation of DNA from mammalian cells: Protocol I. In: Nolan C, editor. Molecular cloning: A laboratory manual, 2nd ed. New York: Cold Spring Harbor Laboratory Press, 9.16-9.19.

Schulz WA (1998). DNA methylation in urological malignancies. Int J Oncol 13:151-167.

Sherman L, Sleeman J, Herrlich P, and Ponta H (1994). Hyaluronate receptors: Key players in growth, differentiation, migration, and tumor progression. Curr Opin Cell Biol 6:726733.

Sy MS, Mori H, and Liu D (1997). CD44 as a marker in human cancers. Curr Opin Oncol 9:108-112.

Tölg C, Hofmann M, Herrlich P, and Ponta H (1993). Splicing choice from ten variant exons establishes CD44 variability. Nucleic Acid Res 21:1225-1229.

Van Steenbrugge GJ, Van Weerden WM, De Ridder CMA, Van Der Kwast TH, and Schröder FH (1994). Development and application of prostatic xenograft models for the study of human prostate cancer. In: Motta M and Serio M, editors. Sex hormones and antihormones in endocrine dependent pathology: Basic and clinical aspects. Amsterdam: Elsevier Science, 11-22.

Van Weerden WM, De Ridder CMA, Verdaasdonk CL, Romijn JC, Van Der Kwast TH, Schröder FH, and Van Steenbrugge GJ (1996). Development of seven new human prostate tumor xenograft models and their histopathological characterization. Am J Pathol 149:1055-1062.

Verkaik NS, Trapman J, Romijn JC, Van Der Kwast TH, and Van Steenbrugge GJ (1999). Down-regulation of CD44 expression in human prostatic carcinoma cell lines is correlated with DNA hypermethylation. Int $\mathrm{J}$ Cancer 80: 439-443.

Zappa M, Ciatto S, Bonardi R, and Mazzotta A (1998). Overdiagnosis of prostate carcinoma by screening: An estimate based on the results of the Florence Screening Pilot Study. Ann Oncol 9:1297-1300.

Zingg JM and Jones PA (1997). Genetic and epigenetic aspects of DNA methylation on genome expression, evolution, mutation, and carcinogenesis. Carcinogenesis 18:869882. 